\title{
Bel Sekolah Otomatis Berbasis Arduino yang Dikontrol Menggunakan Aplikasi Mobile
}

\section{(Automatic School Bell Based on Arduino Controlled By Mobile Application)}

\author{
Muh Pauzan ${ }^{1}$, Indri Yanti ${ }^{2}$
}

\begin{abstract}
The school bell is one of the important devices in school. It has been used from years ago to the present. Bell has been improved along with time. Nowadays, research about school bell has been focused on the bell's controller, such as using software in a computer, placing a keypad on the bell, and even controlling the bell's schedule, which can only be performed using coding. However, these controllers are not practical; therefore, an efficient school bell is made by using an Android-based application as the controller. Bluetooth is used as a communication tool between the smartphone and the bell. The research method was by conducting a literature study and doing a survey to SDN 1 Sarapati Indramayu. Based on the method, it has been decided to make four modes on the Android application, i.e., regular mode, exam mode, free, dan emergency mode. Regular mode is used in a normal condition, and exam mode is used when the students are doing an exam. If teachers want to ring the bell directly, the free mode is operated. There are four types of bell ring in free mode, i.e., once, twice, three, and four-time rings. Emergency mode is useful when the school is in an emergency, such as earthquakes, floods, and fires. Results show that the maximum range to control the bell is $9 \mathrm{~m}$.
\end{abstract}

Intisari-Bel sekolah adalah salah satu alat yang penting di sekolah, digunakan dari dahulu sampai saat ini. Seiring dengan perkembangan zaman, bel sekolah juga mengalami kemajuan. Penelitian tentang bel sekolah saat ini banyak yang difokuskan pada pengontrol bel, seperti menggunakan perangkat lunak di komputer, menggunakan keypad yang ditempatkan pada bel, bahkan mengatur jadwal bel berbunyi yang hanya dapat dilakukan melalui pemrograman. Pengontrol-pengontrol tersebut tidak praktis, sehingga dibuat bel dengan pengontrol yang lebih praktis, yaitu aplikasi berbasis Android. Bluetooth digunakan sebagai alat komunikasi smartphone dengan bel. Metode yang dilakukan adalah melakukan studi literatur dan melakukan survei di SDN 1 Sarapati, Indramayu. Berdasarkan kedua hal tersebut, dibuat empat mode pada aplikasi Android, yaitu mode reguler, ujian, bebas, dan mode darurat. Mode reguler digunakan pada kondisi normal, sedangkan mode ujian digunakan jika siswa sedang melaksanakan ujian. Jika guru hendak membunyikan bel secara langsung, digunakan mode bebas. Pada mode ini, dibuat empat tipe bunyi bel, seperti bunyi sekali, dua kali, tiga kali, dan empat kali. Mode darurat digunakan ketika sekolah dalam keadaan darurat, seperti terjadinya gempa bumi, banjir, dan

${ }^{1}$ Departemen Teknik Komputer Fakultas Teknik Universitas Wiralodra, Jl. Ir. H. Juanda Km.03 Singaraja 45213 INDONESIA (tlp: 0234-275946; fax: 0234-273040; e-mail: muhpauzan.ft@unwir.ac.id)

${ }^{2}$ Departemen Teknik Sipil Fakultas Teknik Universitas Wiralodra, Jl. Ir. H. Juanda Km.03 Singaraja 45213 INDONESIA (email:indriyanti.ft@unwir.ac.id) kebakaran. Hasil pengujian menunjukkan bel dapat dikontrol pada jarak maksimum 9 m.

Kata Kunci-Bel Sekolah, Pengontrol Bel, Aplikasi Berbasis Android, Bluetooth.

\section{Pendahuluan}

Bel merupakan penanda suatu kegiatan dimulai atau berhenti di sekolah. Lima belas sampai dua puluh tahun yang lalu, bel listrik sudah digunakan secara manual, dengan dipencet oleh petugas atau guru. Saat ini, bel sekolah yang tersedia sudah semakin canggih, seperti memiliki fitur otomatisasi, yaitu petugas atau guru tidak perlu lagi memencet setiap masuk, istirahat, ganti jam pelajaran, ataupun saat waktu pulang. Penelitian terkait bel sekolah juga sudah banyak dilakukan, seperti mengenai bel sekolah berbasis komputer [1]. Komputer berfungsi sebagai pengontrol waktu bel dibunyikan. User interface dibangun menggunakan Delphi dan dari perangkat lunak inilah jadwal bel berbunyi diatur. Sinyal keluaran dari komputer berfungsi untuk mengontrol relay. Jika kondisi relay on, speaker akan menyala. Penelitian yang sama juga telah dilakukan, yaitu membuat bel otomatis berbasis Personal Computer (PC) dengan aplikasi user interface menggunakan Delphi [2]. Penelitian lainnya membuat bel sekolah menggunakan PC, tapi perangkat lunak yang digunakan untuk membuat user interface adalah Visual Studio [3]. Bel yang dibuat pada penelitian-penelitian tersebut memiliki kekurangan seperti boros energi, yaitu daya komputer berkisar dari 65 watt sampai 250 watt. Selain itu, pengontrol yang digunakan adalah aplikasi di komputer. Hal tersebut tentu tidak praktis karena setiap kali jadwal bel perlu diubah, petugas harus membuka aplikasi di komputer. Selain tidak praktis pengontrol bel menggunakan komputer juga berdimensi besar dan berat. Berikutnya, dibuat bel otomatis berbasis Raspberry Pi [4]. Tentu saja bel ini lebih praktis dari segi ukuran dan lebih murah dari segi harga, jika dibandingkan dengan yang menggunakan PC. Akan tetapi, kelemahan pengontrol bel ini adalah pengaturan jadwal bel berbunyi harus dilakukan menggunakan komputer atau laptop yang dihubungkan menggunakan kabel ke bel [4]. Penelitian lainnya melakukan pembuatan bel otomatis berbasis Arduino Uno. Ditinjau dari segi harga, penggunaan Arduino Uno lebih murah, dengan kemampuan sama dengan Raspberry Pi. Namun, sistem ini tidak praktis karena pengontrol jadwalnya menggunakan push button [5] dan aplikasi di komputer [6]. Penelitian berikutnya menjawab kekurangan tersebut, dengan membuat bel otomatis menggunakan Arduino Uno yang dikontrol menggunakan web browser [7]. Jadwal bel dapat diatur di mana pun karena berbasis internet. Penelitian lain juga memanfaatkan website 
TABEL I

KonEKSI PIN RTC DS3231 DENGAN ARduINo NANO

\begin{tabular}{|c|c|}
\hline RTC DS3231 & Arduino Nano \\
\hline SDA & A4 \\
\hline SCL & A5 \\
\hline VCC & $+5 \mathrm{~V}$ \\
\hline GND & GND \\
\hline
\end{tabular}

TABEL II

KONEKSI PIN I2C LCD DENGAN ARDUINO NANO

\begin{tabular}{|c|c|}
\hline I2C LCD & Arduino Nano \\
\hline SDA & A4 \\
\hline SCL & A5 \\
\hline VCC & $+5 \mathrm{~V}$ \\
\hline GND & GND \\
\hline
\end{tabular}

TABEL III

KONEKSI HC-05 DENGAN ARDUINO NANO

\begin{tabular}{|c|c|}
\hline Hc-05 & Arduino Nano \\
\hline RXD & TXD \\
\hline TXD & RXD \\
\hline VCC & $3,3 \mathrm{~V}$ \\
\hline GND & GND \\
\hline
\end{tabular}

sebagai pengontrol belnya, tetapi menggunakan Arduino Mega pada bel [8]. Pengontrol bel berbasis website memerlukan biaya yang cukup tinggi karena biayanya harus ditambah untuk penyewaan hosting, pembelian router, dan pembelian Ethernet Shield. Untuk menghemat biaya dan agar sesuai dengan kebutuhan, sebenarnya tetap dapat dibuat bel yang dikontrol secara wireless dengan jarak dekat tanpa mengurangi kemudahan untuk mengontrol jadwal bel berbunyi. Untuk mengatasi masalah tersebut, dirancang dan dibangun bel otomatis menggunakan Arduino Nano yang dikontrol melalui aplikasi mobile berbasis Android. Aplikasi dibuat menggunakan MIT App Inventor. Konsep dari aplikasi ini ditentukan berdasarkan hasil studi literatur dan survei yang dilakukan di SDN 1 Sarapati, Indramayu. Aplikasi tersebut memiliki fitur pengaturan jadwal yang terdiri atas mode reguler, mode ujian, mode bebas, dan emergency. Board yang digunakan adalah Arduino Nano, yang dipilih karena ukurannya yang paling kecil serta harga yang lebih murah dibandingkan dengan board Arduino lainnya. Dengan menggunakan Arduino Nano, bobot bel menjadi lebih ringan dan dan dimensi bel menjadi lebih kecil. Hal baru lainnya adalah komunikasi antara bel dengan aplikasi di smartphone dilakukan menggunakan Bluetooth, sehingga baik dari segi fungsi maupun kepraktisannya, tidak jauh berbeda dengan sistem yang menggunakan sambungan internet.

\section{Metodologi}

Proses pembuatan bel sekolah dimulai dari membaca artikelartikel ilmiah tentang bel sekolah. Hal tersebut bertujuan untuk menganalisis kekurangan dan kelebihan bel yang sudah ada. Selain itu, dilakukan survei ke SDN 1 Sarapati, Kecamatan Karanganyar, Indramayu, untuk mengetahui secara detail jadwal bel dibunyikan, mulai dari bel masuk sampai dengan bel pulang, baik saat jadwal pelajaran (hari normal) maupun saat

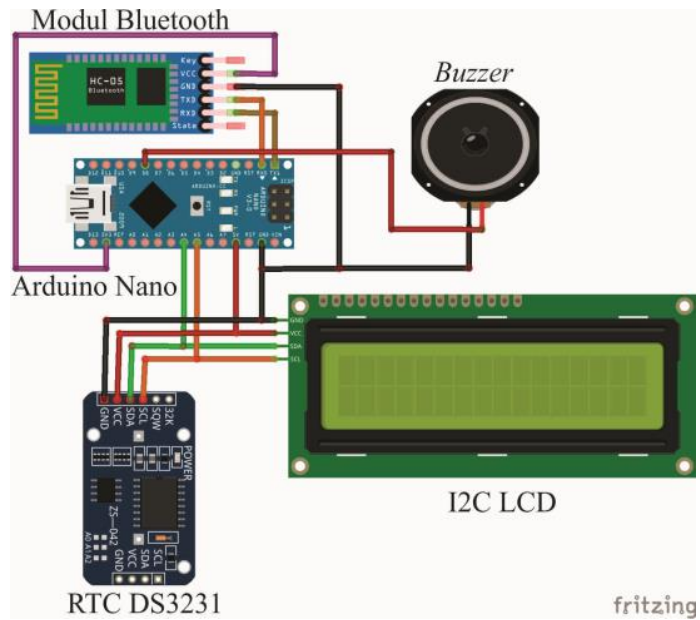

Gbr. 1 Koneksi DS3231, Hc-05, I2C LCD, dan buzzer dengan Arduino Nano.

ada jadwal ujian. Data yang diperoleh kemudian dijadikan rujukan untuk membuat aplikasi berbasis Android serta pembuatan program pada Integrated Development Environment (IDE) Arduino. Pembuatan alat secara detail dijabarkan sebagai berikut.

\section{A. Rancangan Perangkat Keras}

Pada tahap ini, dibuat skema rangkaian antara Arduino Nano dengan RTC DS3231, I2C LCD 16x2, modul Bluetooth Hc-05, dan buzzer. Koneksi pin antara RTC DS3231 dengan Arduino Nano diperlihatkan pada Tabel I, koneksi pin antara I2C LCD 16x2 dengan Arduino Nano disajikan pada Tabel II, sedangkan koneksi pin modul Bluetooth Hc-05 dengan Arduino Nano ditunjukkan pada Tabel III. Koneksi tiap pin pada komponenkomponen tersebut diperlihatkan pada Gbr. 1.

Berdasarkan Gbr. 1, hal yang perlu diperhatikan adalah koneksi RTC DS3231 ke Arduino Nano antara SDA ke pin A4 dan SCL ke pin A5 [9]. SDA adalah pin untuk data serial. Pin ini berfungsi sebagai masukan/keluaran untuk I2C serial interface. Oleh karena itu, pin SDA pada DS3231 dihubungkan ke pin SDA I2C LCD. Pin SDA pada Arduino Nano berada pada A4. SCL adalah pin untuk serial clock, yang berfungsi sebagai clock untuk masukan ke I2C yang ada pada LCD. Pin ini digunakan untuk menyinkronkan pergerakan data dalam serial interface. Pin SCL berada pada pin A5 di board Arduino Nano. Pin TXD pada modul Bluetooth Hc-05 dihubungkan ke pin RXD pada board Arduino Nano, sedangkan pin RXD dihubungkan ke pin TXD. Hal ini dilakukan karena saat mengirim data dari aplikasi berbasis Android yang dibuat, data tersebut diterima pertama kali oleh Hc-05. Hc-05 meneruskan data ke Arduino Nano melalui pin TXD [10]. Pin ini berfungsi meneruskan data serial dengan kecepatan 9600 bps. Karena Arduino Nano bertugas menerima data, maka digunakan pin RXD pada board-nya.

\section{B. Rancangan Perangkat Lunak}

Pada tahap ini ditentukan konsep yang akan diterapkan berkaitan dengan program pada board Arduino Nano melalui perangkat lunak IDE Arduino. Urutan kerja alat yang dibuat ditunjukkan pada Gbr. 2. 


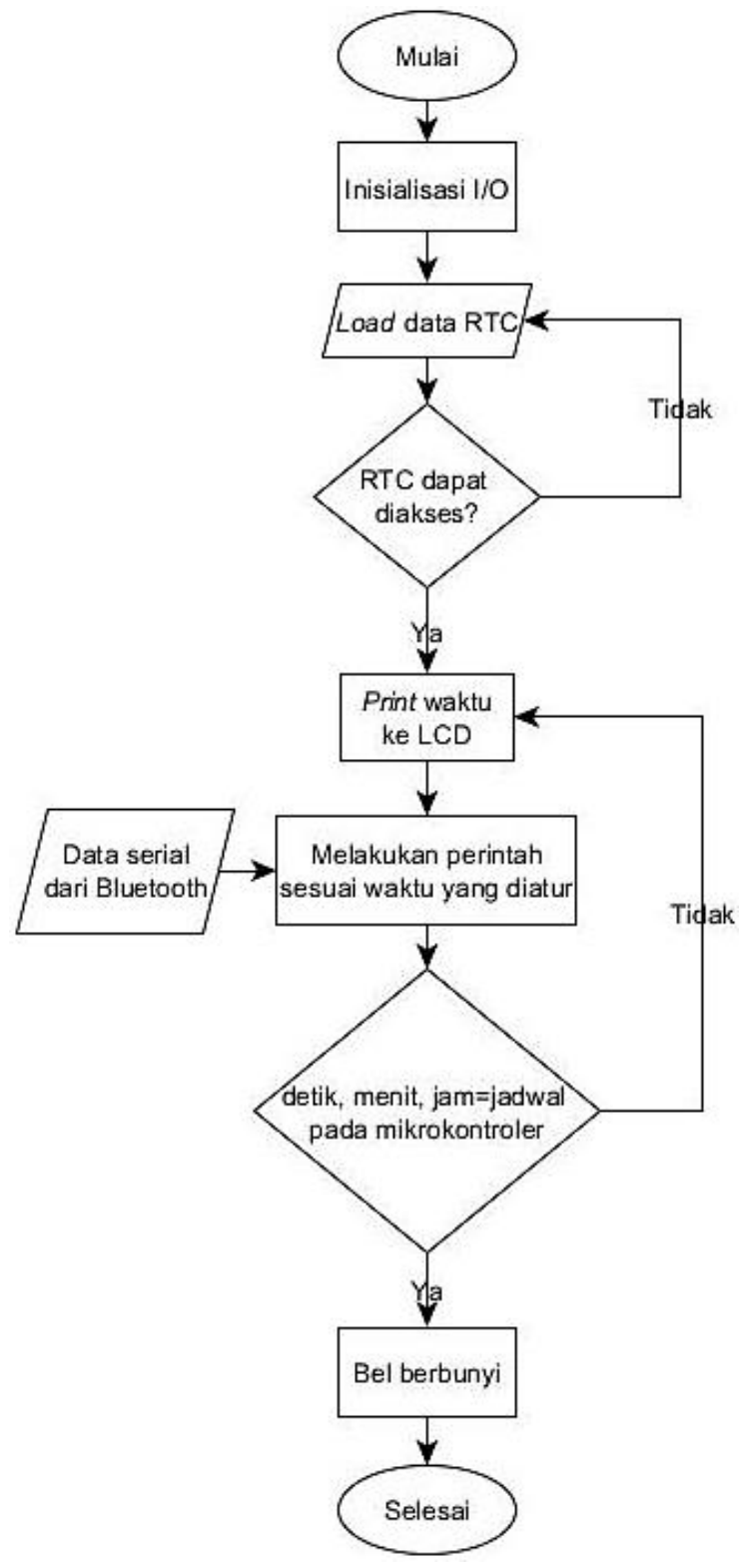

Gbr. 2 Diagram alir cara kerja alat.

Berdasarkan Gbr. 2, saat bel dinyalakan, Arduino Nano menginisiasi pin I/O. Inisiasi ini berada di blok void setup() di IDE Arduino. Data berupa jam, tanggal, bulan, dan tahun didapatkan dari RTC DS3231, kemudian data tersebut ditampilkan melalui LCD. Selanjutnya, Arduino Nano menunggu perintah dari aplikasi di smartphone. Komunikasi keduanya dilakukan menggunakan Bluetooth. Aplikasi di smartphone mengirimkan data serial, lalu Arduino menerima dan mencocokkannya dengan program di dalamnya. Jika data yang diterima sama dengan program untuk menyalakan bel satu kali, maka Arduino akan membunyikan bel satu kali. Demikian juga untuk mode yang lain.

\section{Perancangan Aplikasi Mobile Berbasis Android}

Aplikasi mobile dibuat menggunakan aplikasi MIT App Inventor. MIT App Inventor adalah sistem pembuatan aplikasi Android berbasis website. App inventor diciptakan oleh Google tetapi saat ini dikelola oleh Massachussetts Institute of Technology (MIT). MIT App Inventor bersifat open-source, serta berbasis visual block programming. Pada MIT App Inventor, digunakan empat konsep saat membuat aplikasi mobile pengontrol bel, yaitu jadwal reguler, jadwal ujian, bel dapat dibunyikan kapan saja, serta tombol emergency. Dari konsep inilah dihasilkan user interface seperti pada Gbr. 3 . Tampilan aplikasi setelah pengguna menekan tombol "lihat jadwal reguler" dan "lihat jadwal ujian" diperlihatkan pada Gbr. 4.

Cara penggunaan aplikasi mobile ini adalah cukup dengan menekan tombol yang dikehendaki. Jadwal reguler dan jadwal ujian mengikuti hasil survei yang dilakukan ke SDN 1 Sarapati. Cara kerja aplikasi ini adalah saat salah satu tombol ditekan, data bertipe char dikirim ke modul Hc-05. Sebagai contoh, data yang dikirim adalah " 2 " untuk menyalakan bel satu kali. Hc-05 kemudian meneruskan "2" ke Arduino Nano. Program pada board tersebut sudah diatur agar jika data yang diterima berupa "2" dengan tipe data char, bel dinyalakan satu kali. Demikian juga untuk mode lainnya.

\section{Cara Kerja Alat}

Cara kerja alat ditunjukkan pada Gbr. 5. Penjelasan cara kerja alat tersebut adalah sebagai berikut.

1. Saat bel dinyalakan, Arduino Nano pertama kali akan mengakses waktu dan tanggal dari RTC DS3231.

2. Data tersebut kemudian diteruskan ke I2C LCD sehingga akan muncul jam serta hari, tanggal, bulan, dan tahun pada layar I2C LCD.

3. Jika modul Bluetooth Hc-05 mendapatkan data serial dari aplikasi di smartphone, data tersebut akan diteruskan ke Arduino Nano

4. Arduino akan mencocokkan data yang diperoleh dengan program yang sudah ada di dalam mikrokontrolernya.

5. Jika data yang diterima sama dengan data di dalamnya, Arduino Nano akan langsung mengeksekusi blok program yang ada di dalam data tersebut.

\section{HASIL DAN PEMBAHASAN}

\section{A. Realisasi Perangkat Keras dan Lunak}

Setelah komponen-komponen yang diperlukan dirangkai, selanjutnya dilakukan unduh program dari IDE Arduino ke board Arduino Nano. Kemudian, dilakukan instalasi aplikasi pengontrol bel pada smartphone. Langkah terakhir adalah menghubungkan bel dengan aplikasi menggunakan Bluetooth. Tampilan bel tampak depan diperlihatkan pada Gbr. 6(a), sedangkan rangkaian di dalam bel ditunjukkan pada Gbr. 6(b).

Berdasarkan Gbr. 6(a), smartphone yang sudah terkoneksi dengan modul Hc-05 selanjutnya diuji coba dengan menekan salah satu tombol di aplikasi smartphone.

\section{B. Keputusan pada Setiap Kondisi}

Jika pengguna menekan tombol "bunyi satu kali" di aplikasi yang dibuat, dari smartphone dikirim data dengan nilai " 2 " bertipe data char. Arduino Nano akan melakukan eksekusi karena sesuai dengan program di dalamnya. Syntax program pada IDE Arduino untuk kondisi ini adalah sebagai berikut. 


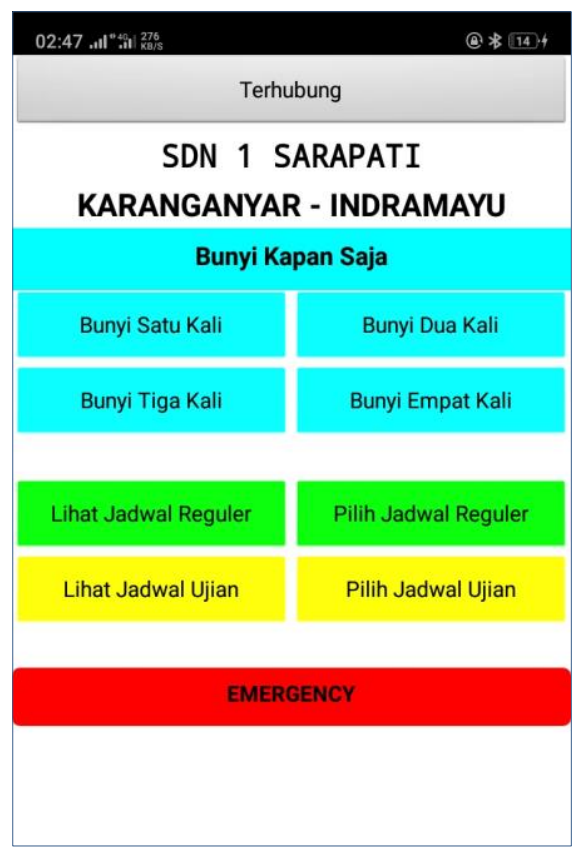

(a)

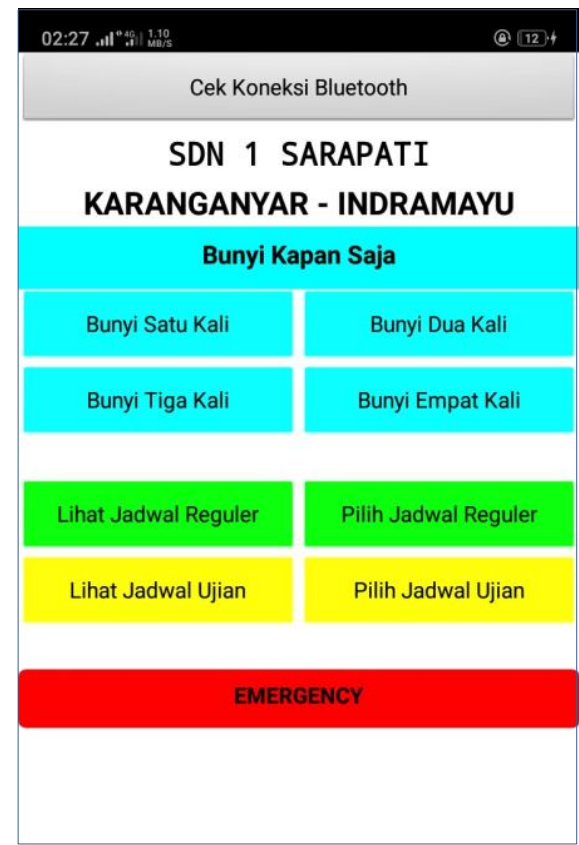

(b)

Gbr. 3 Tampilan user interface, (a) sebelum smartphone terkoneksi dengan bel, (b) setelah smartphone terkoneksi dengan bel.

\begin{tabular}{|c|c|}
\hline \multicolumn{2}{|c|}{$\begin{array}{l}\text { SDN } 1 \text { SARAPATI } \\
\text { KARANGANYAR - INDRAMAYU }\end{array}$} \\
\hline \multicolumn{2}{|c|}{ Jadwal Ujian } \\
\hline Masuk I & 07:00 WIB \\
\hline Istirahat | & 09:00 WIB \\
\hline Masuk II & 09:30 WIB \\
\hline Istirahat || & $11: 30$ WIB \\
\hline Masuk III & 12:00 WIB \\
\hline Pulang & 15:00 WIB \\
\hline \multicolumn{2}{|c|}{ Kembali ke Menu Utama } \\
\hline
\end{tabular}

(a)

\begin{tabular}{|c|c|}
\hline \multicolumn{2}{|c|}{ 02:27. 0} \\
\hline \multicolumn{2}{|c|}{ Jadwal Reguler } \\
\hline Masuk I & 07:00 WIB \\
\hline Istirahat | & 09:15 WIB \\
\hline Masuk II & 09:45 WIB \\
\hline Istirahat II & 11:45 WIB \\
\hline Masuk III & 12:10 WIB \\
\hline Pulang & 13:00 WIB \\
\hline \multicolumn{2}{|c|}{ Kembali ke Menu Utama } \\
\hline
\end{tabular}

(b)

Gbr. 4 Contoh tampilan beberapa mode, (a) jadwal bel berbunyi saat sekolah normal, (b) jadwal bel berbunyi saat ujian.

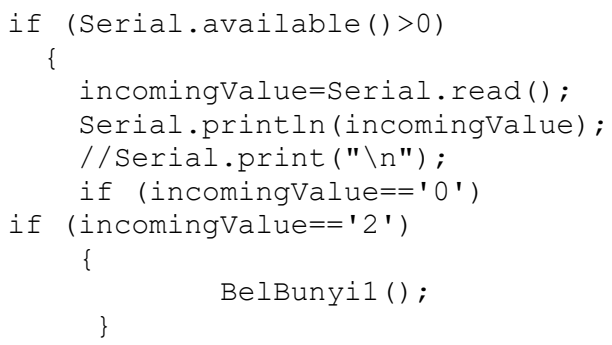

Fungsi BelBunyil ( ) adalah fungsi yang dideklarasikan di tempat lain. Fungsi ini membunyikan bel sekali dengan durasi 5 detik. Berdasarkan syntax di atas, jika data serial yang diterima Arduino Nano tidak sama dengan " 2 ", blok if yang ada di dalamnya tidak dilakukan.

Untuk tombol "Bunyi Dua Kali", data yang dikirim oleh aplikasi di smartphone adalah "3”. Supaya bel berbunyi dua kali, dideklarasikan sebuah fungsi bernama BelBunyi2 () . 


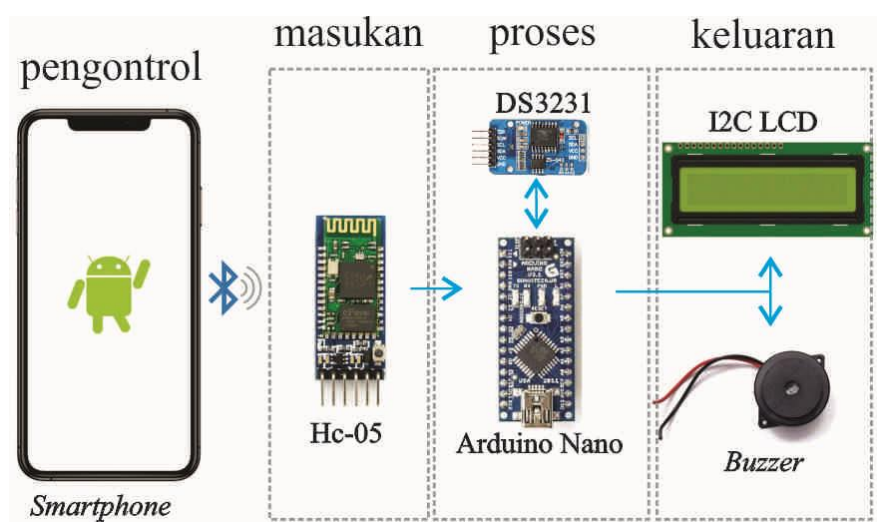

Gbr. 5 Cara kerja bel.

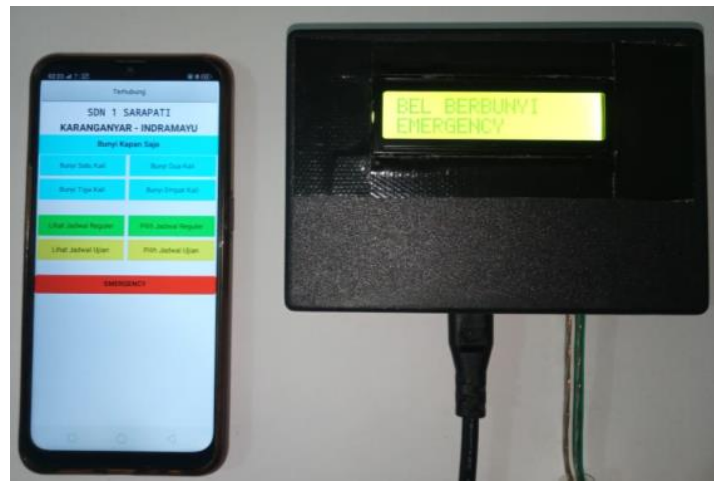

(a)

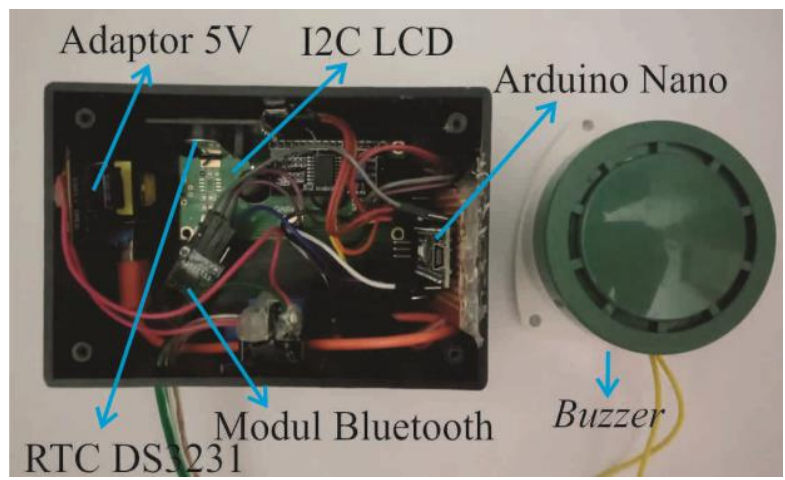

(b)

Gbr. 6 Perangkat keras bel, (a) bel tampak depan, (b) rangkaian pada bel.

Pada fungsi ini, bel diatur untuk berbunyi 2,5 detik, lalu mati 400 milidetik, kemudian berbunyi lagi selama 2,5 detik. Tombol "Bunyi Tiga Kali" dan "Bunyi Empat Kali" mengirim data, berturut-turut, "4" dan "5" ke bel.

Pada tombol "Emergency" di aplikasi smartphone, data yang dikirim bernilai " 6 " dengan tipe data char. Arduino Nano akan mengeksekusi program jika mendapatkan data bernilai "6", dengan syntax program adalah sebagai berikut.

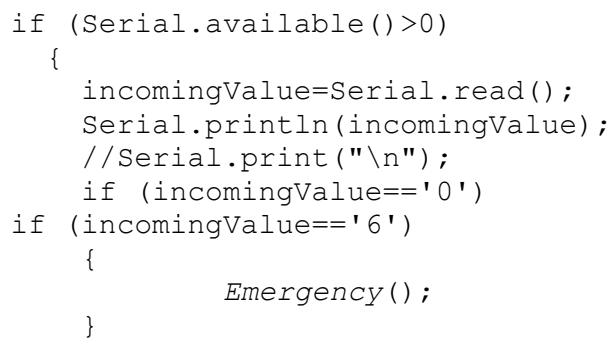

Berdasarkan syntax tersebut, jika diterima data bernilai "6", maka fungsi Emergency ( ) akan dieksekusi. Di dalam tubuh fungsi ini terdapat instruksi untuk menyalakan bel selama 400 milidetik, lalu mati selama 400 milidetik. Hal tersebut berulang sampai 41 kali perulangan.

Syntax untuk membunyikan bel secara langsung di atas tidak dapat langsung diterapkan untuk membunyikan bel yang sudah terjadwal seperti pada tombol "Pilih Jadwal Reguler" atau pada tombol "Pilih Jadwal Ujian" karena saat dipilih tombol-tombol yang dimaksud, Arduino Nano akan langsung mengeksekusi program. Untuk mengatasi masalah tersebut, dideklarasikan variabel bernama a untuk mengeksekusi tombol "Pilih Jadwal Reguler”. Syntax program tersebut adalah sebagai berikut.

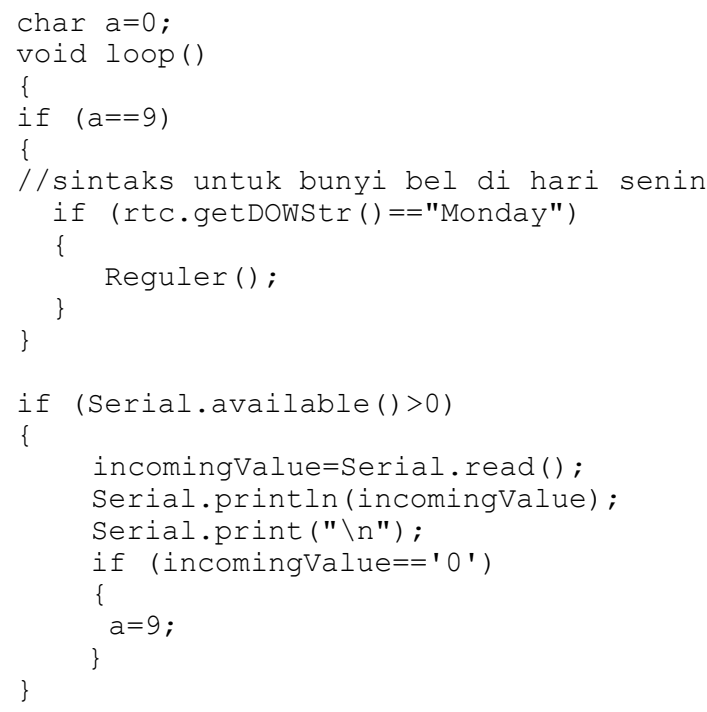

Berdasarkan syntax di atas, jika Arduino Nano memperoleh data dari Hc-05 bernilai "9", maka variabel a yang sebelumnya bernilai "0" berubah menjadi "9". Jadi, komunikasi Bluetooth dengan bel hanya berfungsi untuk mengubah nilai variabel a 
saja. Setelah variabel a bernilai "9", maka blok yang ada di dalam statemen if $(a==9)$ akan dieksekusi. Blok yang ada di dalamnya memanggil fungsi Reguler(). Syntax dari fungsi ini adalah sebagai berikut.

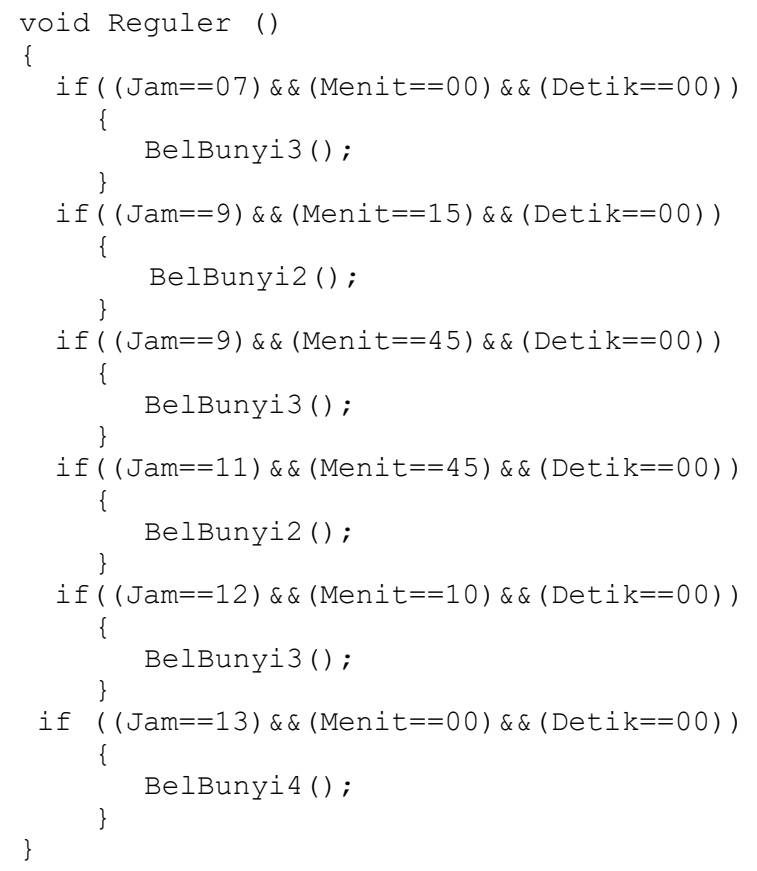

Berdasarkan fungsi Reguler() tersebut, bel dibunyikan dari jam masuk pagi sampai jadwal pulang. Saat masuk kelas, bel dibunyikan dua kali, saat istirahat dibunyikan tiga kali, dan saat pulang dibunyikan empat kali. Hal ini diwakili oleh fungsi BelBunyi2(), BelBunyi3(), dan BelBunyi4() berturut-turut.

Tombol "Pilih Jadwal Ujian" digunakan untuk membunyikan bel pada waktu siswa melaksanakan ujian. Digunakan cara yang sama dengan syntax pada tombol "Pilih Jadwal Reguler" di atas, hanya saja dideklarasikan variabel bernama bo dengan nilai awal sebesar "0". Jika Arduino Nano menerima data dari Hc-05 bernilai "1", maka nilai variabel bo berubah menjadi "11". Jika b bernilai "11", maka bel dibunyikan sesuai dengan jadwal ujian.

Tipe data sangat penting untuk dipahami. Tipe data yang digunakan untuk komunikasi serial antara aplikasi di smartphone dengan Arduino Nano adalah tipe data char. Pada percobaan dengan tipe data yang lain, data yang dikirim diterima berbeda oleh Arduino Nano. Hasil analisis menunjukkan bahwa data yang dikirim dari smartphone diubah ke bentuk American Standard Code for Information Interchange (ASCII) saat data tersebut diterima oleh Arduino Nano sehingga perintah yang diberikan ke bel tidak dapat dieksekusi.

\section{Pengujian Bel}

Selanjutnya, dilakukan uji coba dengan mengirim data ke bel pada jarak bervariasi, mulai dari $1 \mathrm{~m}$, lalu $2 \mathrm{~m}, 3 \mathrm{~m}, 4 \mathrm{~m}, 5 \mathrm{~m}$, $6 \mathrm{~m}, 7 \mathrm{~m}, 8 \mathrm{~m}, 9 \mathrm{~m}$, dan $10 \mathrm{~m}$. Jarak dari $1 \mathrm{~m}$ sampai $10 \mathrm{~m}$ dipilih karena dalam datasheet Hc-05 disebutkan bahwa rentang maksimum komunikasi adalah < $100 \mathrm{~m}$ [10] dan
TABEL IV

MENGUJI BATAS KONEKSI ANTARA SMARTPHONE DENGAN BEL

\begin{tabular}{|c|c|}
\hline Jarak (m) & Status \\
\hline 1 & Pengontrol bel bekerja dengan baik \\
\hline 2 & Pengontrol bel bekerja dengan baik \\
\hline 3 & Pengontrol bel bekerja dengan baik \\
\hline 4 & Pengontrol bel bekerja dengan baik \\
\hline 5 & Pengontrol bel bekerja dengan baik \\
\hline 6 & Pengontrol bel bekerja dengan baik \\
\hline 7 & Pengontrol bel bekerja dengan baik \\
\hline 8 & Pengontrol bel bekerja dengan baik \\
\hline 9 & Pengontrol bel bekerja dengan baik \\
\hline 10 & Pengontrol tidak dapat bekerja \\
\hline
\end{tabular}

Bluetooth di smartphone dapat berkomunikasi dalam jarak yang lebih pendek [11]. Pengujian dilakukan dengan cara menghubungkan smartphone dengan bel melalui koneksi Bluetooth. Hasilnya pengujian ditunjukkan pada Tabel IV.

Berdasarkan Tabel IV, pada jarak $10 \mathrm{~m}$ komunikasi antara smartphone dengan bel tidak berjalan, meskipun di datasheet Hc-05 memiliki frekuensi radio $2,4 \mathrm{GHz}$ [10], yang artinya rentang komunikasi bisa mencapai $>10 \mathrm{~m}$ jika dihubungkan dengan perangkat Bluetooth lain yang memiliki spesifikasi sama. Akan tetapi, perangkat Bluetooth yang ada di smartphone didesain untuk komunikasi dalam jarak dekat [11], sehingga berdasarkan uji coba yang dilakukan, diperoleh jarak maksimum $9 \mathrm{~m}$. Dengan jarak tersebut, guru/petugas dapat mengontrol bel dengan jarak sekitar tiga ruang kelas dari bel ditempatkan.

\section{KESIMPULAN}

Berdasarkan hasil rancang bangun bel sekolah otomatis yang telah dilakukan, dapat disimpulkan bahwa data yang dikirim oleh smartphone ke modul Bluetooth Hc-05 mensyaratkan data dalam bentuk char. Jika digunakan format data selain char, data dari smartphone akan dikonversi ke bentuk ASCII oleh Hc-05. Kemudian, pengontrol dapat bekerja dengan baik dengan jarak maksimum $9 \mathrm{~m}$ dari bel ditempatkan.

\section{UCAPAN TERIMA KASIH}

Disampaikan terima kasih kepada Lembaga Penelitian dan Pengabdian (LPPM) Universitas Wiralodra yang telah membiayai penelitian ini melalui skema Hibah Penelitian Internal Tahun 2020.

\section{REFERENSI}

[1] M.S. Sungkar, "Perancangan Otomatisasi Bel Sekolah dengan Autopower Menggunakan Interface Berbasis Desktop," J. Inform. J. Pengemb. IT Poltek Tegal, Vol. 2, No. 2, hal. 84-89, 2017.

[2] A.L. Affandy, "Rancang Bangun Bel Sekolah Otomatis Berbasis Personal Computer (PC)," J. Informatika, Vol. 8, No. 3, hal. 194-206, 2017.

[3] M.S. Riyadi, "Implementasi Aplikasi Bel Sekolah Otomatis untuk Membantu Pergantian Jam Belajar pada SDN 2 Brebes," Publicitas, Vol. 1, No. 1, hal. 1-5, 2015.

[4] M. Subianto, "Sistem Bel Otomatis Terprogram Berbasis Raspberry Pi," SMATIKA, Vol. 05, No. 1, hal. 5-12, 2015.

[5] Sarmidi dan A. Nurtado, "Simulasi Bel Sekolah Otomatis Berbasis Arduino Uno," J. Manaj. dan Tek. Inform., Vol. 3, No. 1, hal. 121-130, 2019. 
[6] A. Linarta dan N. Nurhadi, "Aplikasi Bel Sekolah Otomatis Berbasis Arduino Dilengkapi sengan Output Suara," INFORMATIKA, Vol. 10, No. 2, hal. 1-7, 2018

[7] D. Satria, Y. Yanti, dan M. Maulinda, "Rancang Bangun Sistem Penjadwalan Bel Sekolah Berbasis Arduino Uno dengan Antarmuka Berbasis Web Menggunakan Ethernet Web Server," J. Serambi Eng., Vol. II, No. 3, hal. 141-147, 2017.

[8] A.T. Setiawan, "Rancang Bangun Bel Sekolah Otomatis Menggunakan Mikrokontroler Arduino Mega dengan Antarmuka Berbasis Web," Sem.
Nas. Inov. Teknol.(SNITek 2019), 2019, hal. 68-80.

[9] “RTC DS 3231 Datasheet," Maxim Integrated, 2015.

[10] "Hc-05 Bluetooth Module," ITead Studio, 2010.

[11] J.F. Ensworth dan M.S. Reynolds, "Every Smart Phone is a Backscatter Reader: Modulated Backscatter Compatibility with Bluetooth 4.0 Low Energy (BLE) Devices," 2015 IEEE Int. Conf. RFID (RFID 2015), 2015, hal. $78-85$. 